\title{
BOSS CHRISTIANS: THE BUSINESS OF RELIGION IN THE "WENZHOU MODEL" OF CHRISTIAN REVIVAL
}

\begin{abstract}
Nanlai Cao*
In the last quarter-century the southeast coastal city of Wenzhou has become the largest urban Christian center in China. Popularly known as "China's Jerusalem" (Zhongguo de Yelusaleng 中国的耶路撒冷), Wenzhou is home to an estimated 700,000-1,000,000 Christians (Protestant) and over 1,200 churches. ${ }^{1}$ The Reformera development of Wenzhou Christianity has accompanied Wenzhou's development from an impoverished rural town to a dynamic regional center of global capitalism, the rapid growth of many small and medium-sized familyowned manufacturing enterprises, the emergence of the city as a world outsourcing hub, and the rise of an entrepreneurial class in the same region. A
\end{abstract}

\footnotetext{
I am very grateful to Andrew Kipnis, Philip Taylor and Nicholas Tapp for their support and help during the process of my thesis-writing. I thank Peter Ng, Barend ter Haar, Mandy Scott and Lim Chee-han for their helpful comments on earlier drafts of the paper. Luigi Tomba and the three reviewers have also provided valuable suggestions for revisions. An earlier draft was given at the conference, "Religion and Social Integration in the Chinese World", held at the Chinese University of Hong Kong. Special thanks to Shi Chenxuan for sending me Chinese materials. The research was funded by the Australian National University, the Religious Research Association and the Society for the Scientific Study of Religion.

1 Mo Fayou, A History of Wenzhou Christianity (Hong Kong: Alliance Bible Seminary Press, 1998), estimates that a decade ago at least 12 per cent $(600,000)$ of the local population was Protestant Christian. Given this percentage of Christians and the city's population growth in the past decade, the Wenzhou Christian population has easily reached 700,000 . According to some local church leaders' estimates, the figure is $1,000,000$. Christian growth in Wenzhou relates in part to the laissez-faire governance of religion in the reform era. See Nanlai Cao, "Christian Entrepreneurs and the Post-Mao State: An Ethnographic Account of Church-State Relations in China's Economic Transition", Sociology of Religion, Vol. 68, No. 1 (2007), pp. 45-66.
} 
new entrepreneurial class of Christians, known as "boss Christians" (laoban jidutu 老板基督徒), has emerged and spearheaded local church development. ${ }^{2}$

These boss Christians are private business owners who were among the first to get rich under the reformist state. As a result of Wenzhou's rural past and dramatic urbanization, the overwhelming majority of them are of rural origin. ${ }^{3}$ Like non-Christian Wenzhou bosses, they started their businesses from scratch in the beginning of the reform era as village entrepreneurs, but as Christians they publicly acknowledge having been blessed by God in their business success. ${ }^{4}$

Though Wenzhou's economic success has received nationwide acclaim, Wenzhou bosses have been frequently stereotyped as uncouth, uneducated new rich (baofa $h u$ 暴发户), sarcastically characterized by the saying "they are so poor that they only have money left". In part, the spirituality of the boss Christians is an attempt to prove this stereotype wrong and in this sense reflects a desire common to many new rich across China.

Many of the boss Christians are both successful private entrepreneurs and influential Christian leaders. They explicitly promote the production and management of church development in consumerist and entrepreneurial terms. During my fieldwork in Wenzhou, some boss Christians proudly talked about “the Wenzhou model of church" (Wenzhou moshi de jiaohui 温州模式的教会) as a parallel to the renowned Wenzhou model of economic development. ${ }^{6}$ This article takes "the Wenzhou model of church" as a central metaphor for examining the cultural linkage between the entrepreneurial outlook of the boss Christians and local church development.

By examining the linkages between economic and religious practices, this article might remind the reader of Max Weber's famous argument in The

2 On bosses-led Wenzhou churches, see Chen Cunfu and Huang Tianhai, "The Emergence of a New Type of Christians in China Today", Review of Religious Research, Vol. 46, No. 2 (2004), pp. 183-200, and Nanlai Cao, "Christian Entrepreneurs and the Post-Mao State".

3 In 2004 only 19 per cent of local residents were non-agricultural hukou holders (Wenzhou Statistical Yearbook, 2005, p. 59).

4 For an extended discussion of Wenzhou's village entrepreneurs, see Gong Mu, Duan Jia and Chen Shu, Wenzhou de nongmin qivejia (Wenzhou's Village Entrepreneurs) (Nanning: Guangxi Renmin Chubanshe, 1987). Boss Christians also acknowledge having been blessed by the reformist state, and many of them as church leaders have learned to work with rather than against the local state. Nanlai Cao, "Christian Entrepreneurs and the Post-Mao State".

5 Shi Jinchuan, Jin Xiangrong, Zhao Wei and Luo Weidong, Zhidu bianqian yu jingii fazhan: Wenzhou moshi yanjiu (Institutional Change and Economic Development: The Study of the Wenzhou Model) (Hangzhou: Zhejiang University Press, 2002), p. 373.

6 A number of articles examining the Wenzhou model of development as a regional model of the "socialist market economy" can be found in Shi Jinchuan et al., Zhidu bianqian yu jingii fazhan. 
Protestant Ethic and the Spirit of Capitalism. ${ }^{7}$ Ironically, the Chinese translation of this work is sold in Wenzhou's Christian bookstores and has been widely read by Wenzhou's boss Christians. They see it as a "how to" manual that lends moral support to their dual identities as entrepreneurs and Christians rather than as a critical commentary on capitalism. My view of the relationship between economic and Christian practice differs from both Weber and the boss Christians. On the one hand, unlike Weber, I do not posit a causal relationship between religious ethics and capitalist practice, in either direction. I merely explore the overlaps and congruencies. On the other hand, unlike the boss Christians, I do not accept that the Wenzhou model of the church proves the uniqueness and superiority of Wenzhou Christianity, but rather see this concept as a metaphor through which boss Christians express their conflicting identities as entrepreneurs, Christians, Wenzhou citizens and new rich.

Studies of Chinese Christianity have generally attributed the spectacular growth in church membership during the reform era to contextual factors such as the ideological vacuum left by the collapse of faith in Communism, the liberalization of state religious policy and the dismantling of traditional moral systems. In a systematic analysis of Protestantism since 1979, for example, Alan Hunter and Chan Kim-Kwong emphasize the role of the "spiritual crisis" produced by radical social and political changes. ${ }^{8}$ This explanation is confirmed by Daniel Bays, who concludes that "different forms of Protestantism can offer for intellectuals or the urban middle class identification with the West and modernization, or an eschatological prospect which may appeal to poor peasants left behind by the economic reforms". ${ }^{9}$ In the most recent elaboration of this approach, Fenggang Yang argues that linking with Western modernity is the main attraction of Christianity to urban middleclass people. ${ }^{10}$ Such analyses, while valuable for their wide perspectives, cannot explain how local believers participate in the constitution of Chinese Christianity.

In this article I treat the Christianity of the Wenzhou bosses as a cultural fact deeply rooted in local society. ${ }^{11}$ In so doing, I join the efforts of the anthropologists of Christianity to set aside any prepacked notion of what the

7 Max Weber, The Protestant Ethic and the Spirit of Capitalism, Talcott Parsons (trans.). London: Routledge, 2001 (1904).

8 Alan Hunter and Chan Kim-Kwong, Protestantism in Contemporary China (Cambridge: Cambridge University Press, 1993), p. 170.

9 Daniel H. Bays, "Chinese Protestant Christianity Today", The China Quarterly, No. 174 (2003), p. 502.

10 Fenggang Yang, "Lost in the Market, Saved at McDonald's: Conversion to Christianity in Urban China", Journal for the Scientific Study of Religion, Vol. 44, No. 4 (2005), pp. 423-41.

11 For a historical and systematic account of Wenzhou Christianity, see Mo Fayou, A History of Wenzhou Christianity. 
Christian experience is. ${ }^{12}$ This allows me to explore how macro historical forces of social transformation have been concretized in the everyday practices of boss Christians. Rather than focusing on what Christians believe and why they do so, I examine what boss Christians do when practicing religion and how these religious practices relate to local business practices. In so doing, I build on Adam Chau's study of a popular religion in rural Shaanbei, north-central China. Chau notes the importance of understanding diverse actors' desires and actions in the process of collectively "doing" religion. ${ }^{13}$ This "doing religion" approach is especially appropriate for Wenzhou, where local people are proud of their pragmatism, a way of life that emphasizes practical action (locally called "doing rather than thinking"). ${ }^{14}$

Drawing on nineteen months of ethnographic field research, I show how newly rich entrepreneurs provide the vital financial capital for church-building projects, evangelical organizations and church initiatives. It is these boss Christians, rather than preachers or pastors, who lead the governing committees of Wenzhou Christian organizations. These advantaged believers often promote the city's fame as "China's Jerusalem" and use the notion of "constructing 'China's Jerusalem" to unite the local church communities. ${ }^{15}$ I further discuss how boss Christians use locally developed entrepreneurial logics when investing in infrastructure, establishing investor control over churches, managing church brands, networking and outsourcing the production of church activity. Local church development has benefited directly from the practical logic of boss Christians.

12 A number of recent anthropological studies of local Christianities can be found in Fenella Cannel (ed.), The Anthropology of Christianity (Durham: Duke University Press, 2006).

13 Adam Y. Chau, Miraculous Response: Doing Popular Religion in Contemporary China (Stanford: Stanford University Press, 2006).

14 The regional tradition of pragmatism can be traced back to the period of the Southern Song Dynasty about 850 years ago, when an influential school of thought known as Yongjia (the old name of Wenzhou) espoused the view that commerce was as important as agriculture, and that to enrich the people should be the fundamental principle of government. The "theory of pragmatism" (shigong xueshuo), founded by the Yongjia school, challenged the dominant Confucian view of the day that placed teachers and bureaucrats at the top of social rank and the merchant class at the bottom. See Cai Kejiao, "Wenzhou renwen jingshen chutan" (An Analysis of the Wenzhou Ethos), Bulletin of Zhejiang Normal University (Social Science Edition), Vol. 2 (1999), pp. 28-31.

15 See David Aikman, Jesus in Beijing: How Christianity Is Transforming China and Changing the Global Balance of Power (Washington: Regnery Publishing, 2003), Chapter 9 , for a journalist's account of Wenzhou Christians' pride in Wenzhou's reputation as "China's Jerusalem". An elderly Wenzhou church leader claims that he first used this term in the 1990s in an essay entitled "Wenzhou: China's Jerusalem", which later circulated in the overseas Christian world. 


\section{Investment in Space and Centralized Control}

In the last quarter-century, the Wenzhou church has focused on the building of its institutional structure and the establishment and expansion of religious space. According to a local church preacher, after churches were allowed to reopen in 1979 there was an initial wave of church-building to meet the needs of local church gatherings. However, since 1990 a competition has developed among local Christian communities to "build the most costly church, the most beautiful church and even the tallest cross". In Yueqing County, Wenzhou's most industrialized and prosperous area, most unregistered house churches have erected church buildings. The house churches in the center of the city have all purchased real estate; some have spent 5-6 million yuan and some even over ten million yuan to purchase their gathering sites, in defiance of the central state regulation of religious venues. ${ }^{16}$

This “fever for church-building” (jiantang re 建堂热) highlights the dynamic process of Wenzhou Christian development in which regional political economy, local cultural tradition and religious meaning closely intertwine. ${ }^{17}$ It also reflects the specific way in which local believers negotiate secular social identity and divine power simultaneously. ${ }^{18}$ Individual church members see the acquisition of new church property as an expression of faith, a main indicator of Christian revival and a reflection of the church leader's personal capacity. Consequently, Wenzhou church leaders brag about the high costs of their church buildings and furnishings. When church leaders report their evangelical work at church meetings, the acquisition or construction of new church sites is frequently mentioned as both a main strategy and the most tangible outcome of their evangelization.

For Wenzhou Christians, the notion of the Wenzhou church extends beyond Christian sites in Wenzhou itself to other parts of China and even other countries. A prideful local Christian saying explains: "Where there are Wenzhou businesspeople, there are Wenzhou Christians, and where there are Wenzhou Christians, there are Wenzhou churches". Wenzhou Christians doing business in

16 Wenzhou Christian entrepreneurs actively seek the state's recognition of their technically illegal house churches, by using their smooth social connections with local party cadres. See Nanlai Cao, "Christian Entrepreneurs and the Post-Mao State".

17 The real estate craze is a reality across China today. Helen F. Siu, "The Cultural Landscape of Luxury Housing in South China: a Regional History", in Jing Wang (ed.), Locating China: Space, Place and Popular Culture (London and New York: Routledge, 2005), pp. 73-93, portrays and analyzes the transformation of a regional landscape in postMao Guangdong through the lens of the consumption craze for luxury private housing.

18 See Jeanne H. Kilde, When Church Became Theatre: The Transformation of Evangelical Architecture and Worship in Nineteenth-Century America (Oxford: Oxford University Press, 2002), for a discussion of the connection between church architecture and religious experience and practice. 
other places are eager to establish their own churches and are reluctant to cooperate with local Christians in their church-building projects. A Christian businessman who does business in a North China city said: "I advocate that we Wenzhou people build our own Wenzhou church in other places (waidi 外地) to establish a brand. Through this brand, others will say the Wenzhou people are powerful (lihai 厉害); they can build such a luxurious church elsewhere to let others attend. This is very good testimony". This Christian boss is the vice-head of the Wenzhou chamber of commerce in that northern city, and told me how he used the chamber's network to spread the gospel in the city in order to "let the city be blessed by Wenzhou people". He firmly rejected the request from the city's two committees (lianghui 两会) ${ }^{19}$ the government-sanctioned Protestant organization, to erect a church building together with a local church. By building an independent church, he hoped to hang out the sign of "the Wenzhou church". According to him, "building churches is more influential than evangelization" and "using the name of the Wenzhou people and of the Wenzhou church to cultivate a positive image is more meaningful". In the end, the two committees approved the purchase of land for this new Wenzhou church project in this North China city.

In line with this cultural logic, there are also large Wenzhou churches in Europe, particularly in Italy, Spain and France, the three main destinations for Wenzhou migrants. ${ }^{20}$ These costly immigrant churches are a source of great pride for local Christians in Wenzhou. Instead of being integrated into Western or even other overseas Chinese Christian communities, the "Wenzhou model" of churches in Europe operates on a basis of autonomy and maintains close transnational ties to the church communities back in Wenzhou, resembling the business dealings of Wenzhou immigrant enclaves in Europe. ${ }^{21}$ These immigrant Wenzhou churches regularly invite Wenzhou preachers to preach in Europe in Wenzhou dialect, and pay their travel expenses. ${ }^{22}$

19 The China Christian Council (Zhongguo jidujiao xiehui) and the Committee of the ThreeSelf Patriotic Movement (sanzi aiguo yundong weiyuanhui) are colloquially called the two committees (lianghui). Established in 1954, the two committees are the officially-recognized Protestant bodies in China. They functionally overlap and are often viewed as one organization.

20 David Aikman, Jesus in Beijing, Chapter 9, also notes the rising number of Wenzhou Chinese churches in Europe.

21 See Wang Chunguang and Jean-Philippe Béja, "Wenzhou ren zai Bali: yizhong dute de shehui rongru moshi" (The Wenzhounese in Paris: A Unique Model of Social Integration), Chinese Journal of Social Science, Vol. 6 (1999), pp. 106-19.

22 Usually, the Wenzhou preachers and church leaders travel on business visas with invitation letters issued by immigrant Wenzhou Christian firms overseas. This convenient arrangement circumvents certain restrictions imposed by the Religious Affairs Bureau on cross-border religious exchange, and greatly facilitates the circulation of people, resources and ideas between the Wenzhou churches overseas and those back home. 


\section{The Big Church Dream and Its Fulfillment}

Many Christian leaders are also real estate bosses, who are commonly known in the church community as having "the gift of buying church buildings" (mai tang de enci 买堂的恩赐). They have profited from dealing in real estate in Wenzhou and across China.

Simply sharing and promoting a big church-building plan can be thrilling for those real estate bosses who like to dream big. Brother Luo is a Christian boss who has an investment company in Shanghai and made a fortune through investing in real estate. ${ }^{23}$ Luo always carries a portfolio in his leather business case that contains a project description entitled "Proposal for constructing a tenthousand-person church in Shanghai", and he is always ready to share this big plan with great zeal in meetings and encounters, formal or informal. Thinking about this great vision makes him too excited to sleep at night. On a number of occasions, he has also shared a dream of building a church in central China so large that it could make the Guinness Book of Records. The big-church dream reflects the popular ideology of petty entrepreneurialism and consumerism in Wenzhou society that emphasizes extravagant new spending on housing and other conspicuous consumer goods. ${ }^{24}$ The big-church dream also reflects the Wenzhou desire to worship in large group settings for a fervent spiritual atmosphere (locally called huo re 火热). ${ }^{25}$

Boss Christians both finance and promote big-church dreams. They often promise a great amount of money well before the idea of a building plan is finalized. One big garment factory boss (who also has real estate in several parts of the country) announced in a church meeting that if his church decided to purchase a local badminton stadium as a new church site (which would cost about 7 million yuan), he would contribute 1.5 million yuan immediately. Local believers earnestly view such a public display of piety and wealth as a reflection of both "God's grace" and one's "great confidence in God's plan".

Raising funds for church-building also parallels local practices for raising capital for family business. Wenzhou church projects usually combine donations

23 Names of individual informants and churches have been changed in this paper to ensure anonymity.

24 Kristen Parris, "Local Initiative and National Reform: The Wenzhou Model of Development", The China Quarterly, No. 134 (1993), p. 259. To dream big and be flamboyant is a modern urban virtue nowadays, not only in Wenzhou but across China. It helps boost one's confidence in business practices and presents the essential capacity and credibility in a transitional economy that is full of uncertainties.

25 For honghuo (social heat), a notion similar to huo re that characterizes the most desirable mode of peasant sociality in rural China, see Adam Y. Chau, Miraculous Response, Chapter 8 . 
and informal lending. ${ }^{26}$ Informal lending enables a great number of local Christians who lack immediate financial capital or ministry and pastoral resources to set up their own churches. The practice greatly shortens the period between the planning for a new church and the completion of church construction or a churchspace purchase.

Quite often the acquisition of new church property rests on the decision of a few entrepreneurs, or even just one. Brother $\mathrm{Hu}$ recalled the process of buying a 1,500-square-meter church space in an office building, and how ardent church members urged him to make the largest contribution:

Initially I was unsure but I was moved by their great confidence and zeal. They said if I decided not to buy, they would find it very difficult [to buy the site]. They said, "You are not only one of the church leaders but more importantly you are the main source of finance". In the end, my contribution to the church accounted for more than one-third of the total funding needed.

Like many other local churches, Hu's church followed standard business procedures in financing church acquisitions. Table 1 is the annual account summary information sheet posted in Hu's church and displayed as a PowerPoint presentation at the church's annual believers' general meeting (xintu dahui 信徒 大会). ${ }^{27}$ Its format resembles an enterprise's year-end fiscal report. The church has taken loans from several sources including banks, other local churches, individual believers and a private enterprise, and has rented out more than half of its purchased space (800 square meters) to a well-known garment company. ${ }^{28}$ In 2005 the church collected 249,000 yuan in rent to help pay for its loans. The rent was to go up to around 300,000 yuan in 2006. Hu plans to reclaim the space from the company in three years.

26 It is a common practice for Wenzhou people to pool their money together in a single investment project, and the use of traditional self-organized credit associations (hui) is the most popular means of grass-roots fundraising in Wenzhou society. See Shi Jinchuan et al., Zhidu bianqian yu jingii fazhan, Chapter 10. On Wenzhou's ritual donation drives, see Mayfair M. Yang, "Putting Global Capitalism in Its Place: Economic Hybridity, Bataille, and Ritual Expenditure", Current Anthropology, Vol. 41, No. 4 (2001), pp. 477-509.

27 The annual general meeting is also called the big council (da yihui), which is composed of all the church members, in contrast to the small council, which is the power center of the church. Although Wenzhou churches have increasingly adopted the Western church council system as their authority structure, the small council is functionally equivalent to the traditional committee of church affairs, and seems only a more democratic, international and fashionable term used in the Wenzhou church community.

28 Bank loans are usually obtained by individual church members in the form of personal housing mortgage. 
Table 1: Annual Account Summary Information Sheet (2005) (In Yuan)

\begin{tabular}{lr}
\hline Previous debts (by the end of December 2004) & $\mathbf{3 , 6 2 0 , 0 0 0 . 0 0}$ \\
Previous balance & $\mathbf{9 , 4 4 4 . 9 0}$ \\
Revenue & $\mathbf{1 , 2 1 7 , 3 4 4 . 7 0}$ \\
Contributions & $745,634.70$ \\
Rent & $249,000.00$ \\
Personal mortgage & $124,000.00$ \\
Other revenue (hymn-book sales and waste recycling) & $2,710.00$ \\
Interest-free loan & $90,000.00$ \\
Expenditure & $\mathbf{1 , 1 8 , 4 9 4 . 6 0}$ \\
Church affairs & $179,914.10$ \\
Reimbursement* & $830,000.00$ \\
Interest paid & $108,580.50$ \\
Balance & $\mathbf{9 8 , 8 5 0 . 5 0}$ \\
Total debts & $\mathbf{2 , 8 8 0 , 0 0 0 . 0 0}$ \\
Hu's company & $1,000,000.00$ \\
The Jianan meeting point & $100,000.00$ \\
The Nancheng church & $200,000.00$ \\
The Beicheng church & $200,000.00$ \\
Brother Yu & $40,000.00$ \\
Interest-free loan & $40,000.00$ \\
Bank loan** & $1,300,000.00$ \\
\hline
\end{tabular}

*Reimbursement (Sister Liu: 20,000; Brother Chen 400,000;

Sister Lin 20,000; Brother Hu 40,000; Sister Zhu 50,000).

**Bank loan (300,000 without interest, 1,000,000 with interest).

Though such religious space is not for productive use, the congregation often views it as a collective commercial asset that will appreciate in China's booming real estate market. ${ }^{29}$ The economic logic of such fixed-asset investments has contributed to the dramatic revival of Christian sites in Wenzhou.

Hu's congregation used to be a youth fellowship affiliated with a major local church. Before moving into the new office building in early 2004, they met in a rented peasant house that was later torn down during an urban renewal campaign. By acquiring the large church space, the new church gradually gained legitimacy among local church communities and established its own independent

This shows that nonproductive ritual economy of expenditure intimately coexists with capitalist social processes in Wenzhou. See Mayfair M. Yang, "Putting Global Capitalism in Its Place". 
institutional structure. As a result, church membership has risen from several dozen to a few hundred in a short period. One of the church's immediate goals is to achieve a thousand registered members. This is an example of how the acquisition of church worship space greatly facilitates the formation and development of Christian subjects. ${ }^{30}$ A middle-aged pastor explained the connection between the expansion of church space and the growth of church membership as follows. "In Wenzhou, if you build a new church, it immediately fills up", he said. "You build another church, and it fills up too. That's the way it is here". ${ }^{31}$ Indeed, Wenzhou Christianity has expressed its intense religious energy and expanded its influence through the massive reappropriation of sacred space. ${ }^{32}$

\section{Ownership, Control, and the "Church Management Responsibility System"}

The fast expansion of church property has fostered new power relations within the church community. The multiplicity of sources of investment inevitably leads to ambiguous church ownership. In fact, conflicts over control of the church have become commonplace in the reform era. Unlike corporate organizations, churches often lack the legal status to purchase real estate and have great difficulty in obtaining ownership, unless they are registered with the state. ${ }^{33}$ To get around this requirement, the church, ideally, selects the most trustworthy person to assume the role of the legal person who signs the contract on behalf of the church. The common practice is for that person to sign two different contracts: a formal one to obtain the property, and an informal one for the church to claim its ultimate ownership. This arrangement helps the church circumvent the state's restrictions on church property acquisition. However, such ambiguous ownership often results in conflicts within the church. It is not uncommon for churchgoers to buy an apartment for a church gathering but later to be reluctant to transfer ownership to the church. In some cases, multiple ownership is introduced, which causes more conflicts among the various churches involved in financing the property acquisition. For example, when one church was recently relocated due to urban redevelopment, a Christian boss contributed 500,000 yuan to buy a new apartment for their fellowship meetings near the city center, but still more funding was needed from others. At this juncture, a sister from another church contributed 60,000 yuan $(50,000$ yuan from herself and 10,000 yuan from her church group) in the name of her own church. The first donor, however, later returned the latter's money for fear that she would attempt to use the apartment for her own

30 See Henri Lefebvre, The Production of Space, trans. Donald Nicholson-Smith (Oxford: Blackwell, 1991).

31 Quoted in Nicholas D. Kristof, "Christianity is Booming in China Despite Rifts", New York Times (7 February 1993), p. Al6.

32 Mayfair M. Yang, "Spatial Struggles: Postcolonial Complex, State Disenchantment, and Popular Reappropriation of Space in Rural Southeast China", Journal of Asian Studies, Vol. 63, No. 3 (2004), pp. 719-55.

33 See Zhejiang Provincial Religious Affairs Regulations (revised edition, 2006), Chapter 4. 
church services at some point in the future, since the shared underlying logic is that the person "who purchases the property has the say in the church". Certainly it is not easy to reject a donor's request to use the church property, but it is even harder to refuse the offers of such donors and founders to assume leadership roles in the church. Patterns of investment greatly shape the church's ownership and control.

Brother $\mathrm{Hu}$ offered the following account of his church's small council meeting (xiao yihui 小议会):

If we decide to do something and it costs less than 2,000 yuan, there is no need to pass it to the small council for approval. It is enough for me to sign. If spending 20,000 yuan, I need the small council to approve it by raising their hands. In such cases I spread the vision (yixiang 异象) to them and tell them why we should do it. This year we planned to invest 200,000 yuan in Fuquan (Guizhou Province) to do charitable work and open up a new field for evangelization. Most of our small council members said it was not necessary, that we still owed money, and asked why we should be so kind. But I know that without standardization (guifan hua 规范化), ${ }^{34}$ we cannot do things successfully. This problem exists in many churches today. You see, we have bought such a large church space, the current value of which cannot be compared with what we owe. The church is worth more than 10 million yuan, but we only owe 2 million yuan or so. This level of debt is very normal. It should not even be considered as debt at all. I think we, just like an enterprise, should operate on borrowings (fuzhai jingying 负债经营); it is not a problem. If you pay off all the money, you will feel you have nothing to worry about and won't be motivated to work hard. Since we owe debts, we should work hard to motivate more people to make contributions. However, the debts should not restrict the development of other church work. If you pay off all the debts, then your enterprise, oh, not enterprise, your church development, will be restrained. When I made this clear, basically all of them agreed. This is a procedure we must observe. That is, to approve by voting.

Though a seemingly democratic process, it is hard to ignore the fact that $\mathrm{Hu}$, as the biggest donor to the church, enjoys the power to persuade those who may not agree with the logic of "operating on borrowings". According to him, the current market value of the church space is almost twice the cost of when they bought it three years ago, an achievement $\mathrm{Hu}$ likes to talk about. The appreciation of the church property gives the Christian bosses particular leverage among the congregation. Hu speaks just like a chairman of a board of directors.

34 Standardization is usually associated with another popular local term "internationalization" (guoji hua) or "to link up with the international track" (yu guoji jiegui) in daily language use. So lacking "standardization" means lacking a conception of the most international, modern and efficient ways of acting. 
As his narrative shows, Hu sometimes confuses enterprise with church. This is not surprising, given the fact that $\mathrm{Hu}$ is also the chair (dongshi zhang 董事长) of his family-owned enterprise. In addition, three members of the church's small council have opened a shoe factory together under Hu's direct financial support and guidance, and the church members collectively hold 200 shares in the factory at 10,000 yuan per share. The boundaries of entrepreneurial and Christian worlds are quite blurred in the operations of the Wenzhou model of church development. However, symbolically these boundaries remain in the consciousness of most local Christians. The boundaries reflect a fundamentalist belief in the sacred/secular binary. One preacher said, "We don't talk about the issue of preacher remuneration in the church, only the divine work (shenggong 圣工), though remuneration is the basis of divine work". Nevertheless, personal economic relations shape the politics behind the church scene. Hu's mention of the democratic voting procedure has little to do with his notion of "standardization". ${ }^{35}$ Standardization is what $\mathrm{Hu}$ personally perceives as the right direction in developing the church, rather than his reference to a democratic church structure. In fact, the members of his church's small council are not elected. In this way, Hu's church resembles most Wenzhou churches today.

The committee of church affairs (tangwu wenyuanhui 堂务委员会) is the highest authority in the power structure of most large Wenzhou churches. Many local believers explicitly call this committee system a "system of patriarchy" (jiazhang zhi 家长制), since the chair of the committee (tangwu zhuren 堂务主任) is the "general responsible person" (zong fuzeren 总负责人), in charge of the church's central affairs such as the development plan, budget making, church spending, coworker employment and compensation, and preacher invitation. According to some critics within the church, such leaders often use church resources to build personal connections. Though Brother $\mathrm{Hu}$ enjoys preaching regularly, his formal title in the church is "general responsible person", a term that resonates with the "enterprise contract management responsibility system" (qiye chengbao zeren zhi 企业承包责任制) introduced in the early years of economic reform. As the main donor and founder of the church, the general responsible person is often viewed as having full control over the congregation.

Similarly, when I asked one local church sister why her church does not elect its leader, she replied without any hesitation that the responsible person (a middleaged male former boss) is not subject to election because he was the founder of this church after separating from his previous church. "He runs the church like his factory, and he has sovereignty (zhuquan 主权)", she said somewhat helplessly. "Our church won't have much further development, but it won't be very bad either, because he has good guanxi with several other churches". According to her, the church does have elections for church committee members below the level of the responsible person. However, such elections can also involve a lot of

35 However, by adopting a voting procedure, Hu's church is one of the very few "democratic" churches in Wenzhou. 
guanxi-building. ${ }^{36}$ As she recalled, the responsible person's wife was elected as the deacon after privately giving gifts such as fine peanut oil and expensive traditional Chinese tonics to many church members. As perhaps one of the few who rejected the gifts, she commented derisively on the direct link between the responsible person's wife's gift-giving acts and her victory in the church election: "Those who lack knowledge think she has a very good, loving heart".

These examples illustrate how the operation of many Wenzhou churches mirrors not only that of a private enterprise but also that of a family-owned enterprise. Leaders of such churches tend to view their churches as their own children and cannot restrain their intense desire for control. Thus, the patriarchal culture of Wenzhou family-owned enterprises has successfully permeated the religious boundaries of the church.

By pointing out the close connections between a donor/founder status and leadership roles in the church, I do not intend to deny instances of rich bosses giving unconditional help to fellow church members or contributing to church development. In fact, I have heard from several sources the story of a Wenzhou Christian boss in Italy who continually sponsors 35 full-time preachers in a local Wenzhou parish, and who "is not even interested in gaining control over them and seizing power". Local believers praise him for his refusal to exercise entrepreneurial control, and some commented that "he is not even super rich" and "works hard for his money there", which apparently gives his financial contribution greater spiritual and moral weight. These believers, however, framed the entire story as an exception rather than a common practice. As this tale also reveals, it is a usual practice for business people to give money privately and directly to full-time preachers to support their livelihood, an informal arrangement that influences lay-clergy relations in ways that neither party wishes to discuss.

\section{Church Split, Failure and Multiplication}

As some churches grow large, they divide into smaller groups and fellowships based on different age groups or on different residential communities/ neighborhoods. These new church groups may grow rapidly under the leadership of a few ambitious and resourceful believers and eventually claim independence from the home church. Severe conflicts over such fission and independence have become common. According to local church leaders, one of the main reasons is financial management. The numerous fellowships and gathering points are supposed to turn in their financial contributions to the mother church. However, churchgoers are often not clear about or are dissatisfied with the ways the money is spent by the central church leaders. Some church members ridicule the leaders as "religious hegemonists" (jiaoba 教霸) and the church structure as "religious autocracy" (jiaohui zhuanzhi zhuyi 教会专制主义). Gradually, discontent mounts

For an extended discussion of guanxi, see Andrew Kipnis, Producing Guanxi: Sentiment, Self, and Subculture in a North China Village (Durham, NC: Duke University Press, 1997). 
and often culminates in the creation of new churches facilitated by aggressive practices of property acquisition. Thus, new independent churches emerge. Due to great pressure and antagonism from the former church authorities, the new churches tend to place strong emphasis on cultivating horizontal networks with other new churches and avoid the vertical organizational structure of the traditional church.

In some churches, especially house churches, divisions are exacerbated by church leaders' kinship ties and personal tactics. For example, a middle-aged local house church leader described how certain house church leaders act like "commanders-in-chief" (siling 司令) who are in charge of huge wealth and human resources and who demand absolute obedience from members. He sharply criticized one of them for his corruption and despotism, and took his wrongdoings as a sign of his lack of fear of God. Comparing some audacious and arrogant house church leaders with the stigmatized (by house church members) official TSPM (Three Self Patriotic Movement) ${ }^{37}$ church, he said in an obviously sarcastic tone that "the TSPM church may not fear God, but at least they have to report to the government".

There are certain implicit rules governing the dynamics of interchurch relations. The fundamental ones can be summarized as reciprocity and mutual respect. Whoever disregards or transgresses such rules has to pay a price. A young local church leader used to be one of the most popular preachers in the Wenzhou church community but then gained a bad reputation for "stealing sheep" (qiangyang 抢羊) from other churches when he was trying to establish his own independent church with some limited foreign funds. At that time he was an invited guest preacher for another church's youth fellowship on Fridays, but he took the opportunity to persuade the youth to visit his own church in an office building. After negative news about the young preacher spread, church leaders no longer welcomed him. As a full-time preacher leading a small church whose congregation mostly came from outside Wenzhou and whose members were not as rich as the locals, he found his financial situation worsening. He was said to have unabashedly attempted to borrow money from a local Christian entrepreneur and leader who had invited him before.

When recounting the story of this young preacher, some local Christians took it as a negative lesson about how important it is to maintain smooth guanxi in the Wenzhou church. They attributed his failure to gain more new members to his

37 The "Three-Self" principles include self-administration, self-support and self-propagation. The churches registered with the lianghii are usually known as TSPM churches (sanzi jiaohui), and those non-registered churches are often called house churches (jiating jiaohui). For a discussion of the bitter divisions between TSPM and house churches and among the larger Chinese Christian community, see Ryan Dunch, "Protestant Christianity in China Today: Fragile, Fragmented, Flourishing", in S. Uhalley, Jr. and Xiaoxin Wu (eds), China and Christianity: Burdened Past, Hopeful Future (Armonk: M. E. Sharpe, 2001), pp. 195-216. 
isolation, his lack of good guanxi with local entrepreneurs, and his church's small size and lack of "momentum" (shengshi 声势). Though several others praised the courage he demonstrated in breaking away from traditional church forces, it is clear that he damaged his support networks. Without ties to enterprises, entrepreneurs or/and other church organizations, either domestic or overseas, it is difficult to survive as a newly independent church. As one Christian businessman and church leader said, "The bosses are the driving force behind (houfang 后方) church work, while full-time preachers are at the forefront (qianfang 前方) of evangelization".

Ironically, sometimes independent churches unite with one another to counter the pressure of the "hegemonic" traditional church structure. As they grow bigger, however, they sometimes reproduce the centralized vertical organizational structure of the traditional church. The break-up of one large church into separate ones not only energizes the local Christian development but resembles the complex inter-relationship among Wenzhou's family-owned enterprises.

\section{Outsourcing Church Work}

As the case of the disappointed young preacher discussed in the previous section illustrates, a church without good relationships with other churches and parachurch organizations falls behind in the competitive market of faith, in part because it cannot, to use a local Christian bosses' favorite term, "optimize resource integration" (ziyuan youhua zuhe 资源优化组合). Some boss Christian leaders have been explicit about the process of “outsourcing” (waibao 外包) church work through networks when striving to "integrate resources for the sake of Christ" (wei jidu zhenghe ziyuan 为基督整合资源) ${ }^{38}$ In fact, almost all Wenzhou churches, whether house churches or the TSPM churches, whether small or large, are embedded in networks. Their pastoral services and evangelization work are mostly "outsourced" to established local Christian networks that link preachers, entrepreneurs, churches and enterprises. This is particularly reflected in the arrangements for sermons and the production of various large-scale evangelical activities. This "specialized division" (zhuanye hua fengong 专业化分工) of church work has contributed to increasingly professionalized church services in the reform era. For example, preachers regularly rotate among churches, reducing the need for each preacher to come up with a new sermon every Sunday. Similarly, one would never see an evangelization meeting organized by a single Wenzhou church. The underlying organizing principle is "coordinated service" (peida shifeng 配搭事奉) based on specialized division of labor.

Since the withdrawal of the Western missionaries, the Wenzhou church's denominational structure has been replaced by an administrative division in

38 By outsourcing, local entrepreneur church leaders actually mean a process of flexible production based on a specialized division of labor. They sometimes use the term in the church context with a slightly derisive tone. 
parishes (muqu 牧区). Each parish is responsible for dispatching preachers to different churches and gathering points to conduct services. ${ }^{39}$ This preacherdispatch system is called paigong (派工) or paidan (派单). It is actually a system of outsourcing pastoral services, as churches do not necessarily need their own preacher. Each church has a timetable (dan 单) that records the names of the preachers and times of their preaching over half a year or an entire year. Almost all the preachers under this system work on a volunteer basis, and they have daytime jobs. According to a Wenzhou preacher's report published in 1997 in Tianfeng (Heavenly Wind 天风), the official Chinese Protestant magazine, there were only about a hundred full-time pastoral workers and 34 ordained pastors in Wenzhou, and the ratio of these pastors to believers was 1:20,000. Daily pastoral work was thus heavily dependent on a large group of volunteer (yigong 义工) preachers, whose number was around $3,500 .^{40}$

Such volunteer preachers can rely upon a limited number of lecture notes for their sermons, since none of them will be dispatched to a particular church more than twice a year. Many of them, therefore, recycle their sermons in front of different church audiences. This enables busy entrepreneurs and those with little education, either religious or otherwise, to contribute to pastoral work. ${ }^{41}$ Over the past decade, many Christian businessmen have attended various short-term training courses to sharpen their preaching skills. ${ }^{42}$ For boss Christians, preaching is often a way of conspicuously displaying their spiritual (cultural) capital.

The outsourcing of Sunday sermons and other services to volunteer preachers from other churches resolves the biggest problem inherent in fast church growth, the lack of professional pastoral care (muyang 牧养) for individual believers. It is impossible to know who first designed the preacher-dispatch system or

39 The preacher-dispatch system may not work smoothly across the boundaries of the house church and the so-called TSPM church. Although it is common for a TSPM preacher to be dispatched to a house church and vice versa, extremist house church groups strongly object to such arrangements.

40 Shi Chenghui, "Wenzhou jiaohui shi ruhe kaizhan yigong peixun gongzuo de" (How the Wenzhou Church Volunteers' Training Work is Conducted), Tianfeng, Vol. 10 (1997), pp. 8-9. These figures indicate the serious shortage of ministry and pastoral resources in the mid-1990s. After more than a decade of explosive Christian growth in Wenzhou, this shortage may now be even more striking.

41 Many Wenzhou Christians are striving to move upward in the hierarchies of both economy and spirituality. This is neatly captured by a local Christian saying, "Bosses all want to preach while preachers all want to do business". Not surprisingly, there are very few fulltime preachers in Wenzhou; most preachers have their personal business and serve the church on a part-time basis.

42 Among the many formal and informal lay training programs in Wenzhou, the Wenzhou Lay Training Center provides the most systematic training to help church volunteers serve the church. Established in 1995 by the Wenzhou city-level two committees, the center focuses on instruction in preaching, hymn and music studies, and church management. See Shi Chenghui, "Wenzhou jiaohui shi ruhe kaizhan yigong peixun gongzuo de", p. 9. 
contributed to the idea, but according to local churchgoers this is a unique Wenzhou Christian invention under God's special tutelage. As one preacher said,

God has let these volunteers rise in the 1980s when there was an explosion of believers and churches ... if there were no such volunteer coworkers to help with the church's Sunday pulpits, the situation of the church today would be unimaginable. This unprecedented phenomenon is the miraculous work of God Himself.

Nevertheless, the underlying logic is arguably entrepreneurial rather than religious, given the city's international fame as a base for outsourcing production, a local entrepreneurial reality in which tens of thousands of family-controlled firms engage in the flexible, fast and competitive production of small merchandise. ${ }^{43}$ These small firms have relied heavily on a massive number of Wenzhounese itinerant traders who organize production through subcontracting. ${ }^{44}$

Just as in business enterprises, outsourcing decisions are usually based on a mixture of factors: the location of the planned activity/ministry, church leaders' personal connections, past experiences of cooperation and the "comparative advantage" of conducting various church services. For instance, in order to enhance members' commitment, one local church leader proclaims in a church council meeting that his church will seek to "provide the best pastoral services" and “build a brand church" (dazao pinpai jiaohui 打造品牌教会). To achieve this end, his main strategy is to invite the best preachers he can find from other places to engage collectively in the church's pastoral work on a weekly basis, rather than train someone from his own church.

In addition to daily pastoral work, large-scale evangelization events in Wenzhou are also heavily outsourced. Annual Christmas Eve evangelization events serve as a good example. On Christmas Eve 2006, an evangelization meeting held in a local theater drew over a thousand participants from around the city, a grand scene not uncommon in the Wenzhou church's celebration of Christmas in recent years. The event donors and organizers were a group of local Christian entrepreneurs from several different churches. To ensure that the local authorities did not interfere, at the beginning of the event the head of the districtlevel two committees donated 20,000 yuan to the district-level charity federation

43 In the case of cigarette-lighter production, some 3,000 small Wenzhou firms have worked together, with some specializing in components and some in final assembly. In 2002, Wenzhou made 750 million lighters, the equivalent of 70 per cent of world demand. "On the Capitalist Road", The Economist (20 March 2004), p. 14.

44 Yia-Ling Liu, "Reform from Below: The Private Economy and Local Politics in the Rural Industrialization of Wenzhou", The China Quarterly, No. 130 (1992), p. 297; Alan P. L. Liu, "The 'Wenzhou Model' of Development and China's Modernization", Asian Survey, Vol. 32, No. 8 (1992), p. 700. Shi Jinchuan et al., Zhidu bianqian yu jingii fazhan, indicate that a major feature of Wenzhou's rural industrialization is that many villages developed their own specialized industries and wholesale markets. There are ten major specialty market towns that integrate the activities of the household industries and the itinerant traders or sales agents. 
on behalf of these Christian entrepreneurs. As planned, this worked as a cover to label the evangelical meeting as a "charity show". The event took the popular form of a variety show in the following order: first "ballet dancing on a person's head" (dingshang balei 顶上芭蕾, a form of acrobatics), followed by a house church choir performing three hymns, and then a one-hour modern dance drama entitled "The Star of Bethlehem" performed by a professional troupe invited from Nanjing. An itinerant preacher acted as the host of the show, and a Singaporean piano teacher and seminary graduate served as an invited advisor supervising the entire program. Dozens of youths from a local church's youth fellowship acted as ushers.

Many different parties with different agendas and interests are involved in the production of such large evangelization meetings. The main organizers need to decide which choir, troupe, preacher and/or foreign teacher they should invite and when. They coordinate these efforts in a series of planning and preparation meetings to make sure that the program is well sequenced. They also provide well-trained church workers to maintain order at the meeting site. Last but not least, the main organizer needs to be ready to negotiate with local state agencies when unwelcome state intervention occurs.

Although heavily dependent on outsourcing networks, Wenzhou Christian entrepreneurs act innovatively in manufacturing various evangelical activities that appeal to the Christian consumer self. They seek to exert greater control over the overall design of the evangelical program by designating specific speech topics for the invited guests and particular themes for the invited performances. For example, when they invited a Chinese-American Christian and the head of a hightech joint venture as a guest speaker for an evangelical banquet targeting local entrepreneurs, they asked him to talk about his enterprise development, since "this is his specialty", and "our local Wenzhou preachers can lecture better than he does on the cultivation of spirituality (lingming de zaipei 灵命的栽培)".

As the case of Christmas Eve evangelization reveals, Wenzhou Christian entrepreneurs and local churches often collaboratively sponsor a wide range of evangelical activities and initiatives. ${ }^{45}$ In this context, shop fronts, office spaces, factory workshops and chambers of commerce can all become important “spiritual resources" (shuling ziyuan 属灵资源). Moreover, the mix of hosts, partners, sponsors, preachers and performers in these various activities and events can vary, giving the Wenzhou Christian organization great flexibility. Religious production in Christian Wenzhou can thus react quickly to consumption-driven chains of changing religious desires. The flexible production of pastoral work and evangelization contributes to the Wenzhou church's sophisticated adaptability in different local situations, and represents an innovative structure that resembles

45 This mirrors the diversified investment strategy of many Wenzhou Christian bosses. All of these activities and efforts are for the evangelical purpose of Christianizing China. 
that of the Wenzhou model of enterprises with their global-distribution-driven commodity chains. ${ }^{46}$

\section{Learning and Copying from Overseas Christian Models}

Although Wenzhou's urbanization and industrialization began just three decades ago, it has been a transnational society actively engaged in trade and commerce for many centuries. Some half a million people of Wenzhou origin currently reside in over 100 countries and regions, mainly in Europe and the US. ${ }^{47}$ The large expatriate community of Wenzhou people around the world maintains close social, economic and cultural ties with their hometown. Consequently, Wenzhou people often take Western cities (rather than Chinese metropolises such as Beijing or Shanghai) as reference points for the latest fashion trends and new business concepts. These transnational networks have enabled Wenzhou to look outwards and stay on the forefront of China's capitalist development. In a similar way, Wenzhou Christians have imported Bibles and other Christian materials from overseas when such things were still hard to find within China. Over the last few decades, Wenzhou churches have received advice or guidance from a great number of overseas Christians.

Today there are overseas Christians who come to preach and teach in the local church almost every week. During my time in Wenzhou, foreign Christian bands and musicians also performed regularly, producing a "Christian fever" among the local youth. Some were invited by the Wenzhou church while others were attracted to Wenzhou by its international fame as "China's Jerusalem". These overseas Christians came from Hong Kong, Taiwan, Korea, Singapore, the US, Canada, Australia and Holland. Their presence in the local church always drew large crowds. They often received applause and flowers when they ended their speeches or performances. Some enthusiastic local young believers took photos of them or with them, and asked for autographs, treating them like pop stars.

Over the past half-century since the withdrawal of Western missionaries and the founding of the TSPM in an attempt to fend off foreign funds and influence, the role of (mostly clandestine) foreign evangelists in Wenzhou has been transformed by both the restrictive state religious policy and the consumerist local reality. The local Christian community today treats foreign visitors as exotic speakers, lecturers, experts, celebrities and performers rather than missionaries in

46 Gary Hamilton, Commerce and Capitalism in Chinese Societies (London; New York: Routledge, 2006), Chapter 7, uses the term "reflexive manufacturing" to capture Taiwan's integration in the global economy. This also perfectly captures Wenzhou's current pattern of industrialization. I thank David Buck for pointing out this to me.

47 There are no accurate statistics, given the fact that many Wenzhou people are illegal immigrants in Europe. According to a French government's estimate, about 100,000 Wenzhou migrants live in the "Wenzhou town" in Paris. The figure resembles a small European city's population. See Wang Chunguang and Jean-Philippe Béja, "Wenzhou ren zai Bali”. 
the traditional sense. ${ }^{48}$ Representing the highest form of Christian modernity, these overseas Christians have become a significant source from which the local Christian community constantly draws inspiration and legitimacy. Wenzhou Christian entrepreneurs often talk of the need for the Wenzhou church to introduce more overseas Christians to Wenzhou and encourage more local Christians to go abroad (yin jinlai, zou chuqu 引进来, 走出去). In fact, they have made a claim to the high status of overseas Christians through the mass "copying" (mofang 模仿), “learning” (xuexi 学习) and “introduction” (yinjin 引进) of Western or Western-derived cultural and religious forms in local church development.

Desired Western styles are most tellingly reflected in local Christian architecture (see fig. 1). Wenzhou church architecture has always impressed overseas Christians who come for a visit for the first time, with its clearly Western design. "These are often gigantic, ornate structures evocative of large European or North American churches, topped by huge red crosses that are landmarks as you make your way out of the center of town", commented a Christian journalist from the US. ${ }^{49}$ One preacher from southern California

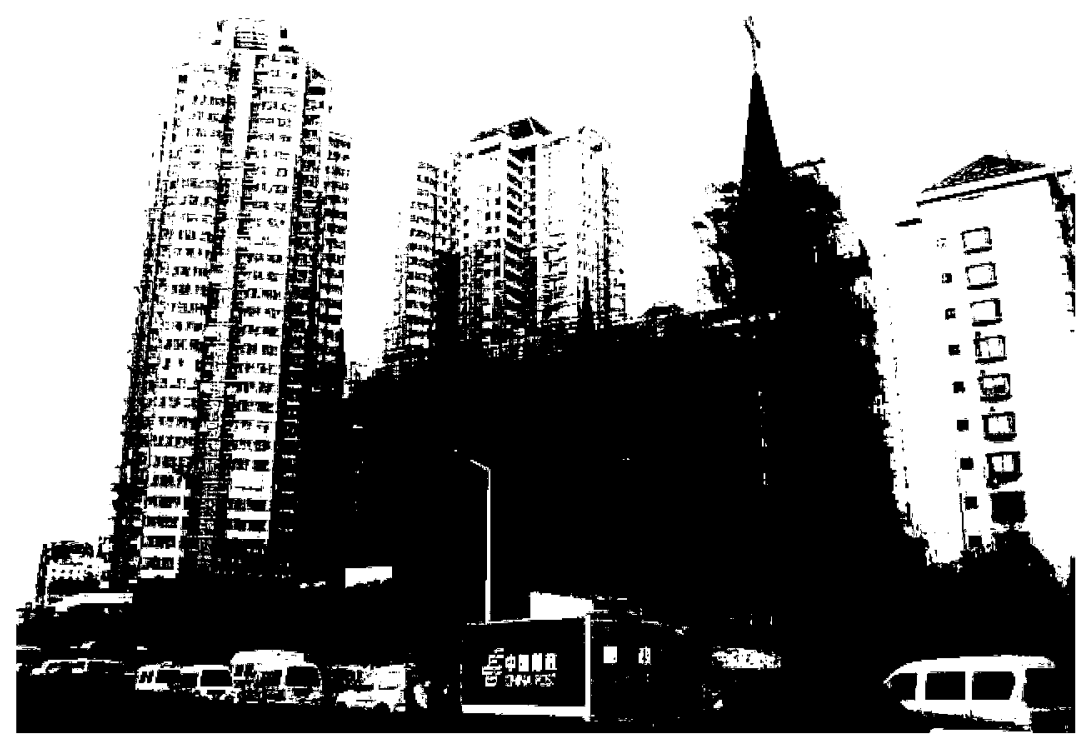

Figure 1. A landmark church under construction at the southeast comer of a busy intersection in the heart of Wenzhou's city district. The building and furnishing project will cost about 15 million yuan (photo by author, 2007).

48 For an account of the early Western missionary enterprise in Wenzhou, see W. E. Soothhill, A Mission in China (Edinburgh: Oliphant, Anderson and Ferrier, 1907).

49 Quoted in David Aikman, Jesus in Beijing, p. 187. 
expressed similar amazement that Wenzhou church buildings reminded him of the orthodox church of the 18 th or 19th century. He said that in the West today church buildings are not like that any more. ${ }^{50}$ Profound economic and technological advancements in the reform era have also contributed to the rapid development of many modern auditorium-style churches in Wenzhou. Many local churches feature prominent theatrical elements such as proscenium arches, marquee lighting, imported stereo systems and sound-mixing rooms, mirroring the nineteenth-century middle-class theater-style church in the US. ${ }^{51}$ Many potential converts are drawn to the local church by the beauty of the site. This architectural style is partly due to Wenzhou's extensive historical exposure to Western (missionary) influences. More importantly, however, images of Western Christian architecture brought back by Wenzhou Christians doing business overseas have strongly inspired local church designs. Take the case of a newly built local church (see fig. 2 and fig. 3). The founder (a middle-aged entrepreneur)

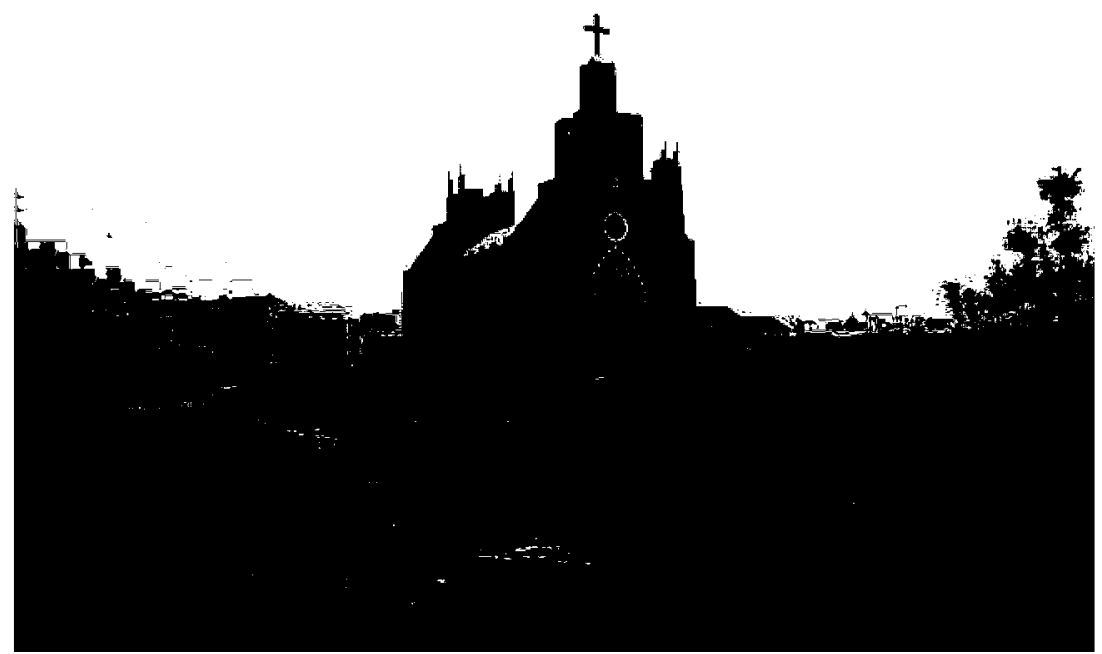

Figure 2. A newly built church in suburban Wenzhou surrounded by rice paddies and family-owned factories. It cost about 12 million yuan. This is a district from which many big Wenzhou entrepreneurs hail and from which a great portion of local population has emigrated overseas. On the façade of the church building, there are two English words, "Evangel Ha1l" (photo by author, 2007).

50 The fact that the entrepreneurial church leaders are copying the old-fashioned Western church style is mainly because they want an "authentically" (zhengzong de) Western church building. When asked why, some simply say that "this is what a church should look like", and other styles may be considered "unspiritual" (bu shuling).

51 Jeanne H. Kilde, When Church Became Theatre. 


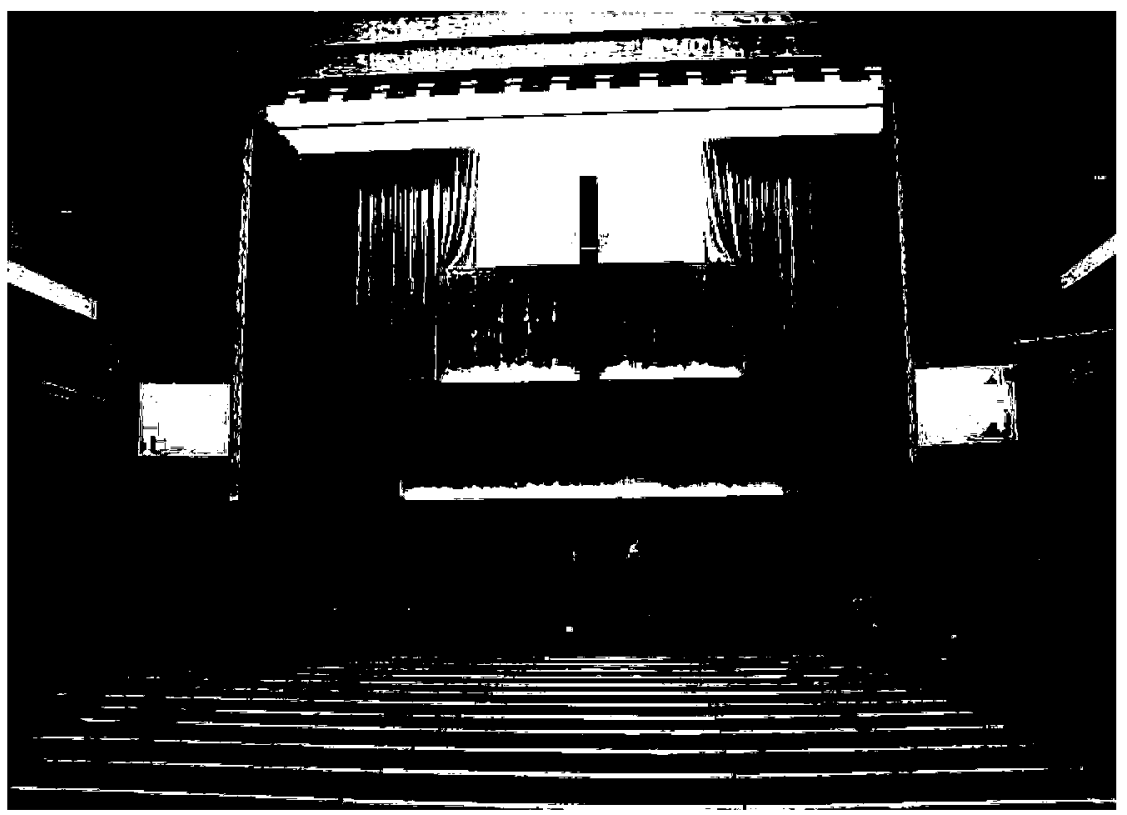

Figure 3. An interior view of the auditorium-style church, featuring rows of fancy oak pews, granite walls, central air-conditioning, an electronically controlled vertically moveable stage (for choir performances), and modern theater lighting and audio-visual equipment (photo by author, 2007).

said that the design of the church was based on many church photos he took while traveling in Europe, and that a local design company helped realize the plan by following his "direction of thought" (silu 思路).

The founding of a ministry center in a local parish in early 2006 serves as another prominent example. The center founder, a former factory boss, borrowed the idea of a ministry center from the Hong Kong church in order to promote professionalized, centrally-managed pastoral services in Wenzhou. Since its establishment, this ministry center has received numerous visitors and guests, both domestic and overseas, and has served as a showcase for the open and modern image of Wenzhou Christianity. When a middle-aged Christian boss, known for his big dreams, shared his plan to set up an elderly activity center in Wenzhou, I heard a middle-aged preacher who was friendly with him make fun of him by saying that he could make his plans "simply by visiting Hong Kong and returning to hold a preparatory meeting in Wenzhou". Albeit a bit of exaggeration, this comment vividly characterizes a Wenzhou model of both business and Christian infrastructure-building, which often relies on copying ideas and concepts from overseas.

Ambitious Wenzhou Christian leaders see learning and copying from overseas Christians not as their ultimate goal but as an essential means for elevating the status of the Wenzhou church in global Christian development. In fact, many 
anticipate the rise of a Wenzhou church model that would be comparable to the status of the Wenzhou economic model and also be widely studied and copied by others. The élite circle of entrepreneurial leaders is most enthusiastic about overseas Christian models in the local church, given their extensive cosmopolitan experiences. Foreign names, places, examples and references keep cropping up in their conversations. A recently established Wenzhou Christian entrepreneurs' fellowship was modeled on the US-based Full Gospel Businessmen's Fellowship. There the organizers share bold visions in fellowship meetings, including founding a Christian culture school as important as Harvard or Cambridge, acquiring a sacred mountain similar to the Prayer Mountain in Korea, building a big landmark church like Korea's Yoido Full Gospel Church (known as the biggest church in Asia), and establishing a Christian foundation as successful as the Amity Foundation.

However, their desire to copy overseas models of Christian development does not imply a lack of desire to export their own. Boss Christians envision an entrepreneur-led Wenzhou model of evangelization in the global Christian mission of what they call "bringing the Gospel back to Jerusalem". They are convinced that Wenzhou's status as "China's Jerusalem" and the existence of a global business network will lead Wenzhou people to "take over the last relay baton" in the great mission of global evangelism, a mission that was started by the Christian West but has never been completed. ${ }^{52}$ One Christian boss commented, "the world looks at China, China looks at Wenzhou, and Wenzhou looks at our Christian entrepreneurs".

This strategy of imitation in local church development, however, is not a Christian invention, nor is it a new invention in the reform era. The ability to imitate (shanyu mofang 善于模仿) has been viewed as a defining feature of the “Wenzhou ethos" (wenzhou ren jingshen 温州人精神) by the Wenzhou bosses themselves. It is also championed publicly in the nationwide fever for "Wenzhou study". ${ }^{53}$ This characteristic of Wenzhou culture has been shaped by the historical practices of household handicraft industry and trade, of which Wenzhou emerged as a main regional center during the Song Dynasty $(960-1276) .{ }^{54}$ The historical continuation of this entrepreneurial culture appears to be closely associated with Wenzhou's geographic isolation and linguistic uniqueness. ${ }^{55}$ In the early years of

52 See Pál Nyíri, "The Yellow Man's Burden: Chinese Migrants on a Civilizing Mission", The China Journal, No. 56 (2006), pp. 83-107, for a discussion of this global Chinese Christian civilizing project.

53 Cai Kejiao, "Wenzhou renwen jingshen chutan".

54 Cai Kejiao, "Wenzhou renwen jingshen chutan".

55 Some scholars have argued that Wenzhou's reform-era economic achievements were more a "renaissance" than a "takeoff". See for example, Alan P. L. Liu, "The 'Wenzhou Model' of Development and China's Modernization", p. 698. This is not to argue that the tradition of entrepreneurship has remained unchanged for centuries, but that it influences the business practices of the Wenzhou bosses today. 
post-Mao reform, imitation was the starting point for many Wenzhou village entrepreneurs in low-end family-owned manufacturing enterprises. ${ }^{56}$ Feeling especially blessed, boss Christians speak positively of imitative efforts in both church development and business development. Some view it as evidence of the powerful entrepreneurial capacity of the Wenzhou people, who have faced harsh conditions characterized by natural geographic disadvantage and minimal state investment. Needless to say, Wenzhou's pioneering status in reform-era economic development benefits largely from transnational connections which also enable the Wenzhou church to achieve a competitive edge in the domestic religious market.

\section{Conclusion}

The practices of Wenzhou boss Christians blend business practices common in Wenzhou's market economy with local church development. This so-called "Wenzhou model" of church development is dominated by an entrepreneurial class of church leaders who actively engage in the massive production and consumption of sacred space across local, regional and even national borders. The imposing Western-style church buildings enable these ascendant capitalists to display their newfound wealth and secure their social status. It is also through the specific process of investment in church space that they gain prestige, authority and power in the local community. The specific pattern of the Wenzhou churches' real estate practice enables the entrepreneurs to translate their economic capital and channel their entrepreneurial logic and skills into daily church operations. The Wenzhou churches have, therefore, mirrored the local pattern of corporate ownership and are controlled by their investors. Aggressive practices of church property acquisition, moreover, have facilitated church splits and multiplication that fuel Christian growth in a manner resembling the multiplication of local business.

The lack of an overarching church authority structure in managing religious practices and symbols has created space for this entrepreneurial class of church leaders to maneuver and to shape the local Christian landscape, particularly through the strategies of outsourcing and copying. The outsourcing system has become a requisite for the Wenzhou churches' fast growth, given the shortage of qualified clergy. It also offers some boss Christians the opportunity to preach themselves, further consolidating their cultural capital. Rapid imitation and duplication of the styles and concepts of overseas churches further enables the Wenzhou model of church development to become increasingly integrated into global Christianity.

56 In the 1980s, Wenzhou was notorious for making counterfeit products, particularly Western brand-name shoes, clothes and lighters. Even today, in the minds of other Chinese, Wenzhou is still linked with fakes and counterfeits, although there has been great improvement in the quality of Wenzhou-made products. 
Through self-conscious and deliberate endeavors to construct "China's Jerusalem", Wenzhou boss Christians have managed to refashion Chinese Christianity, a marginalized rural social institution in the popular imagination, into a modern urban institution with an entrepreneurial outlook. At the same time, they refashion their own class identities, from village entrepreneurs with limited education to highly cultivated Christian leaders. They thus convert economic resources into cultural capital.

By examining Wenzhou Christian entrepreneurial logic on its own terms, this article sheds light on the formation of a new local élite in reform-era urban China. ${ }^{57}$ Since money alone does not define élite status, a sense of social insecurity has developed among China's new rich. For many, the quest for respectability has outweighed the simple desire to get ahead in the emerging market economy. ${ }^{58}$ The "Wenzhou model" of church development is an important element of the local bosses' cultural strategies to distinguish themselves in a particular socio-symbolic world. ${ }^{59}$ While the Wenzhou model of economic development has served as a microcosm of China's rural industrialization and modernization, ${ }^{60}$ the Wenzhou model of Christian development reflects a widespread pattern of élite desire for cultural as well as economic capital.

57 Cf. Adam Chau, Miraculous Response, who portrays a Shaanbei temple boss who embodies characteristics of the two types of new local élite in rural China, the new rich and the moral leader.

58 "Children of Rich Learn Class, Minus the Struggle", New York Times (22 September 2006), p. A1.

59 See Andrew Kipnis, "The Flourishing of Religion in Post-Mao China and the Anthropological Category of Religion", The Australian Journal of Anthropology, Vol. 12, No. 1 (2001), pp. 32-46, on China's post-Mao religious revival as growing arenas of symbolic participation.

60 Alan P. L. Liu, "The 'Wenzhou Model' of Development and China's Modernization"; Yia-Ling Liu, "Reform from Below". 


\section{CONTRIBUTORS TO THIS ISSUE}

Yongshun Cai teaches in the Division of Social Science at Hong Kong University of Science and Technology. His current research focuses on contentious politics in China.

Nanlai Cao is a doctoral candidate in anthropology at the Australian National University. He is completing a dissertation entitled "Constructing China's Jerusalem: Christian Modernity and Regional Development in Post-Mao Wenzhou".

Richard Cullen joined the Faculty of Law, University of Hong Kong, as a Visiting Professor in August, 2006. He was previously a Professor at Monash University. He has spent over 12 years based in Hong Kong, teaching and writing on Hong Kong and China. He has written and cowritten (regularly with $\mathrm{Fu}$ Hualing) several books and more than 130 articles, notes and comments focused on Public Law, Media Law and Tax Law. He is a member of the Hong Kong think tank, Civic Exchange.

Hualing $\boldsymbol{F u}$ is Associate Professor, Faculty of Law, the University of Hong Kong. His research interest includes police power, legal aid and legal institution reform. He teaches human rights in China, corruption, and law and development in China.

Colin Hawes is a Senior Lecturer in Chinese, East Asian and corporate law at the University of Technology Sydney. His research focuses on the intersection between legal reform and culture in China, especially in the areas of corporate, banking and commercial law. He is currently completing a book on the Chinese transformation of corporate culture.

Sebastian Heilmann is Professor of comparative government and the political economy of China at Trier University, Germany. He is the author of The Politics of Economic Reform in China and Russia (2000) (in German) and The Political System of the PRC (2004, updated 2008). His recent research is focused on China's policy process and economic policy-making.

Stanley Lubman has specialized on China as a scholar and as a practicing lawyer for over forty years. He is currently Lecturer at the School of Law and Visiting Scholar at the University of California (Berkeley) and has previously taught at Stanford, Columbia, Harvard and Yale Law Schools as well as others in Europe. From 1978 to 1997, while continuing his academic activities, he headed the China practice at two major San Francisco law firms and a large English firm of solicitors. Professor Lubman has been advisor to The Asia Foundation on legal reform projects on China since 1998. He is the author of Bird in a Cage: Legal Reform in China After Mao (1999), editor of China's Legal Reforms (1996) and coeditor of Engaging the Law in China: State, Society and Possibilities for Justice (2005). 